\title{
Defining a Crisis: Boarding
}

James reached the decisive point. Or was it the point of no return? Either he could turn about and withdraw, or he could continue queuing for boarding, which had started a few minutes before, and get on the aircraft. Either choice would send him in opposite directions-handing the whole of his mindful body over to an unpredictable risk and to the machine of The $M o$, one of those ambitious wannabe-progressive printed (plus online) news magazines James worked for, or putting his early professional reputation in danger. Both options might have different consequences for The $M o$, as well: gaining authority and credibility, or going on with the trend of losing followers without any moment of fluctuation. Both decisions could also interfere in the catastrophe playing out on San Lorenzo, since its causes, the stifling materiality of the tragedy, and its effects were inseparable from their media representations (see Van Loon 2002). Therefore, James also knew that his decision would relate to the individual tragedies of San Lorenzians.

Vertigo. A sudden microsecond of panic, followed by an unwitting tug; and a flash of inspiration, during which James saw all the levels and bends of the entanglement of his own edgy situation, the liminal position of the printed press of The Mo's kind, the catastrophe itself, the historically logical and spatially global roots of the crisis, and, above all, the crisis with all its sharp materiality.

At very first glance, crisis seemed to be a Gordian knot or at least to have a rhizomatic non-structure. As far as James remembered, "crisis"

J. Kotišová, Crisis Reporters, Emotions, and Technology, https://doi.org/10.1007/978-3-030-21428-9_2 
could mean anything. His colleagues and the media in general were using the word to refer to so many different things that they had inflated the use of the term. "Crisis" seemed to have lost any meaning. And scholars have been doing the same: at least from the nineteenth century onward, the enormous quantitative expansion in the variety of meanings of the concept of crisis caused it to lose its clarity, analytical precision, and appeal for social sciences (Koselleck 2006; Vincze 2014). "The term 'crisis' has been too widely diffused in the social sciences to be used innocently any longer" (Wagner 1994: 30). As a result,

'The crisis' has become a catchphrase that can refer to various shortages of resources and goods, material or spiritual, but also the perceived breakdown of governance, institutions or indeed the fabric of society. ... This use of the term contributed to creating a sense of generalized crisis. (Vincze 2014: 567, 579)

The term has encompassed all spheres and has become a commonly employed expression that remains diagnostic but removed from its eschatological explanation (Koselleck 2006).

Yet, the catchphrase was there, in all its amorphousness, defined by its polyvalence and incommensurability of its diverse facets. Often used and always ready to be used. Therefore, understanding the emotional experience of "crisis reporters" without making a journey through the strata of meanings of the word "crisis" in "crisis reporting" would be a lost cause.

Once again, the long wait at the airport and the thought of the crisis that awaited James made him see stars; for a moment, he lost his balance and touched a young and elegant yet tired-looking woman, queuing behind him, with his shoulder.

The passing contact crowned his faintness. His nervousness in the presence of women was increasing with his every next amorous fiasco. Although his girlfriends were typically from within the branch-where else could he meet someone? - at some point, saying "Listen, I have to leave, today, tomorrow, all of a sudden" (a sentence that, as James' colleague Bob once insinuated, could have contributed to his divorce, especially because he used to say it repeatedly) largely complicated having any stable relationship. James had to accept that "Journalism is a way of living, at the end. You learn how to live without plans" (Ines).

The impossibility went well together with independence, his basic necessity, so that the impracticable mixed with the unwanted. Eventually, James stopped distinguishing the two. 


\section{The Polyphonic Nature of "Crisis" Within "Crisis REPORTING"}

James' colleagues' varied understandings of the term suggest that "crisis" is defined precisely by its multiple meaning. The word is like a "Rorschach blot into which I can project diverse things" (Matouš).

For example, Josef discursively interconnected crisis in family (e.g. when someone is ill, which significantly influences a reporter's ability to work even in a non-crisis situation), temporary social crisis (the crisis "out there," involving individual crisis biographies), global risks and crisis of the modern state (from which more and more temporary, local, and biographical crises follow), technological crisis (such as a wrong cable, "God forbid that it's your fault!"), crisis for a media organization (e.g. redoubling the demands on management and personal capacities during crises "out there"), and, above all, personal crisis (none of these circumstances "won't give you a lift," and a personal crisis may result from an emotionally demanding work context such as work with refugees, who themselves are undergoing personal crises). Astrid stressed a diffused technologically driven media crisis residing in poor-quality journalists and more reliance on social media; Louis and Matouš, focusing on national media systems, saw a crisis in the financial problems of media organizations and shrinking newsrooms; Matouš also added media oligarchization, while Jacob spoke about the division of Belgian society. All of these crises resonated and were mutually reinforcing-or otherwise related to-each other to the extent of blurring boundaries between the meanings:

Crisis reporting is when one is sent somewhere, to Baghdad, something is going on-then one is definitely in hard conditions. Not only in difficult life conditions, in danger of one's life, which is the most essential thing, but also seeking information. And the crisis that we go through on work trips is, say, whether we will make it or not, whether we have connection or not-this kind of non-comfort, that is crisis reporting. (Astrid)

Although the boundaries between the diverse meanings of James' colleagues' use of the word "crisis" were often unclear, some distinctions could be made. Or rather, one could trace a few dialogues between the types. In other words, crisis is always contextual, contingent, transcending, and invalidating the inside versus outside, momentary versus permanent, constructed versus real, and global versus local dichotomies. 


\section{Inside-the-Media Is Outside-the-Media Crisis}

As Josef, a permanent foreign correspondent said,

a reporter faces two types of crisis, you know? (...) Either there is a crisis consisting in something that happens, an acute event that of course entails stress, and you must act fast. And the second crisis consists in nothing happening.

Indeed, when James talked with his former and present colleagues about the specifics of crisis reporting, they usually first asked him to clarify whether he meant a crisis inside or outside-the-media: "Well, the question is, whether you mean a crisis situation in the world or in reporting," said Marie, who spoke, similarly to Šimon, Astrid, or Ines, of technological breakdowns or logistic impossibilities during on-the-spot crisis reporting or inside the newsroom. The distinction between inside-the-media and outside-the-media perspectives reflects the difference between two positions/roles: whether the event in question is a routine or non-routine event from the point of view of the journalists themselves, and whether the event is defined as a crisis from the perspective of the affected actors (Olsson and Nord 2015).

Nevertheless, the distinction is not absolute, partly because journalists are actors, too (Peters 2011; Tandoc and Takahashi 2016). Sometimes, these two types resonate, or, conversely, interfere. A foreign crisis such as the earthquake on Haiti, Astrid said, was perceived primarily as an event that could facilitate newsmaking processes, and thus prevent a potential inside-the-media crisis. Similarly, Ema said that "crisis" meant, above all, better teamwork, much more fun (including tacit permission to smoke in the office!), and the desire to stay at work longer. On the other hand, Čestmír pointed to the danger of inside-the-media crisis and the threats to professionalism following from covering an outside-the-media crisis:

From a purely journalistic point of view, crisis zone news is unprofessional, because it introduces only one side of the conflict. (...) Simply because there is a frontline between [the two sides], and it's very hard to cross.

In any case, crisis can be an event that "changes the news fundamentally" (Kryštof). This view is consistent with media researchers' observations that due to the essence of crisis-ness-negativity, high levels of uncertainty, surprise, lack of preparedness and routines-coverage of crisis events is of lower journalistic quality than other types of reporting 
(Falkheimer and Olsson 2015; Nord and Strömbäck 2006; Olsson and Nord 2015; Van Leuven et al. 2013).

James looked above the boarding counter at the screen announcing his destination. The name of the capital of San Lorenzo was missing; instead, the screen was showing the heads of various politicians and officials, reacting to the event. A special broadcast. They knew nothing, maybe even less than James; yet the channel reasoned them into empty performances.

The hollow statements laid bare the resonances of inside-the-media and outside-the-media crisis. The crisis out there sometimes triggered what could be called an organizational crisis: much higher time pressure, chaos, involuntary improvisation, fundamental reassignment of tasks and responsibilities. Authors writing on organizational crisis and crisis management find it difficult to draw a clear line between outer crises, sources of uncertainty, disruption and change that form parts of larger events/states, and internally harmful organizational processes (e.g. Sellnow and Seeger 2013). For example, BP's 2010 Gulf of Mexico oil spill harmed its reputation and financial performance, and its relationships with customers, local communities, and governments (Bundy et al. 2017). Similarly, a major crisis that a media organization was supposed to report on, although not caused by the organization itself, brought about chaos, disruption, and change in newswork routines.

James recalled a situation when he, a rookie beginning at $\check{C} T$, went to cover an anti-immigration demonstration in Prague with experienced reporter $\mathrm{R}$ and cameraman $\mathrm{C}$ :

The meeting in the production department alone is very chaotic. I am waiting in the tunnel. Diverse reporters pass by, picking up cameramen and taking up their technical equipment. All are in a hurry—running here and there, taking something from behind countless doors and putting it back somewhere else. But the camerapeople are smiling and joking. R is coming, we are looking for a cameraman and a driver. $\mathrm{R}$ is twice set right about with whom we are going. No one really seems to know who, with whom and where she shall go, what to shoot and what equipment to bring. Tripodyes, or no? "This is a crisis situation," $\mathrm{R}$ tells me and smiles somewhat crossly. (...) $\mathrm{C}$ is always returning to the people present at the demonstration. 'They make me wanna puke. I think I will throw up on them,' he says. (...) He doesn't throw up, but always throws in an evaluation of the attendees and of the speakers standing on the stage. 'Goddamn motherfuckers. The fucking bastard Zeman ${ }^{1}$, C grinds out. (Field notes)

\footnotetext{
${ }^{1}$ Czech president, known for his anti-immigration rhetoric.
} 
Of course, in comparison, the journalists' published (written, televised) discourse was always much more acritical and homogeneous (cf. Pedelty 1995).

Needless to say that standing in a media pen in the middle of the front rows of demonstrators from Pegida-who came from nearby Dresden to support their fellow Islamophobes - and the like, among the banners and placards with ridiculous but terrifyingly bizarre combinations of symbols, James himself felt very uncomfortable. He took a few pictures (Images 2.1 and 2.2).

And this was a stupid demonstration, James thought. In more serious crises, the disorganization was even more obvious. For example,

Whenever there was a development [after the terror attacks in Paris in November 2015] — like when Abdelhamid Abaaoud, one of the instigators of the attacks, was killed-people [in $\check{C} T$ ] started to move fast and frenetically, and even ran across the newsroom. They were speaking in an agitated way and the tension was almost palpable. (Field notes)

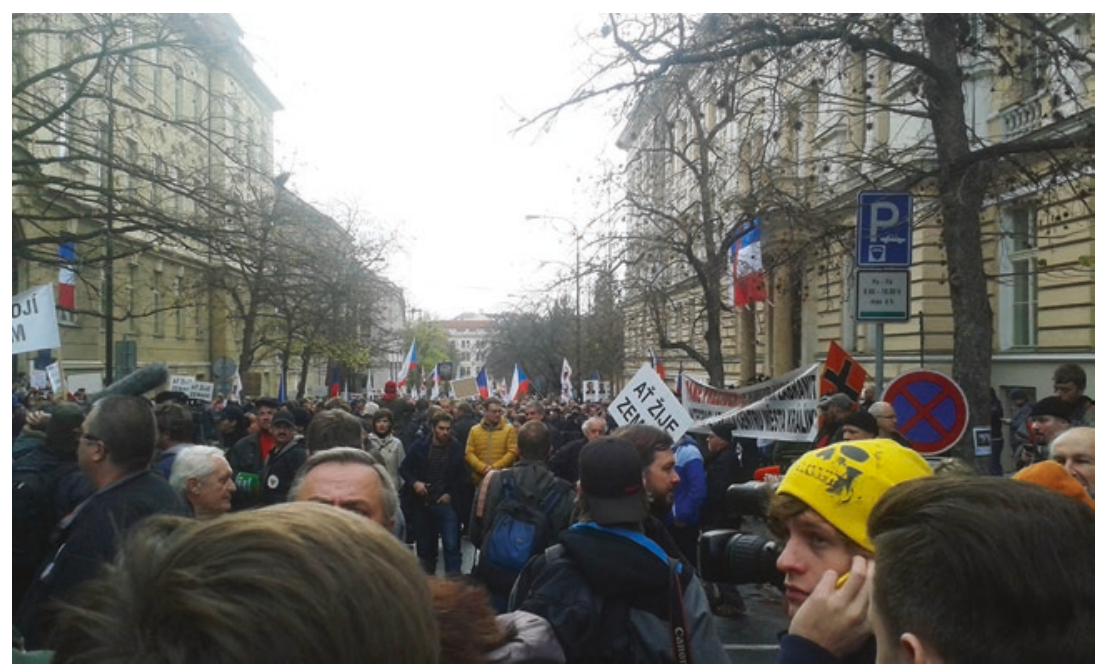

Image 2.1 Demonstration on 17 November 2015, Prague, organized by Bloc Against Islam (Blok proti Islámu), to support Czech president's opinions on immigration and Islam. Picture taken by the author as a part of her fieldwork in Czech Television 


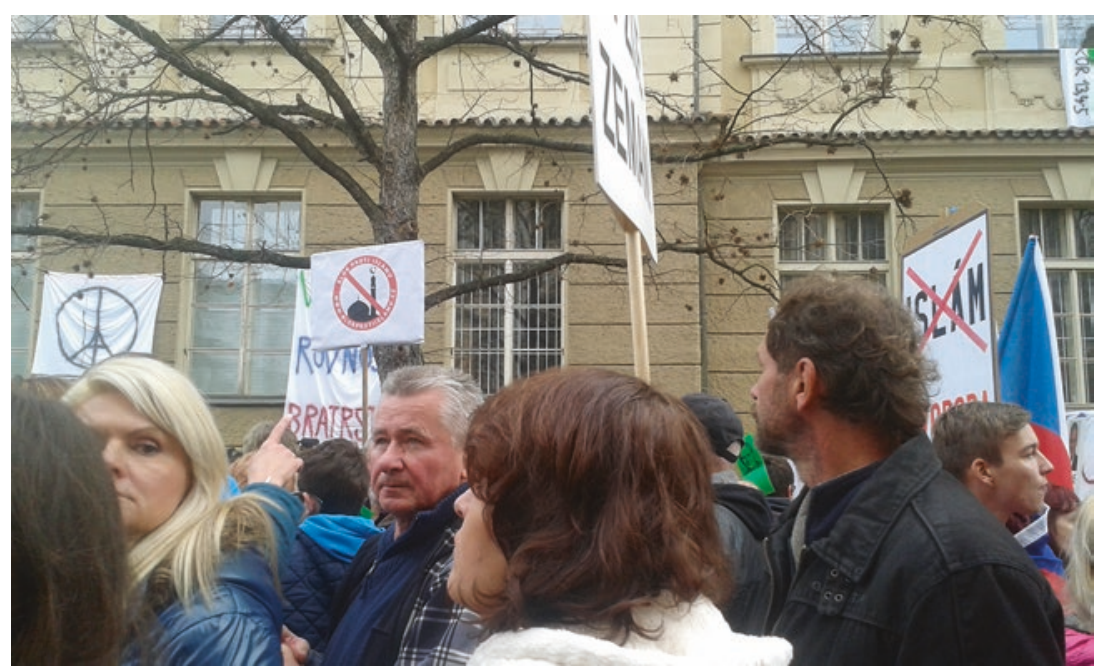

Image 2.2 Demonstration on 17 November 2015, Prague, organized by Bloc Against Islam (Blok proti Islámu), to support Czech president's opinions on immigration and Islam. Picture taken by the author as a part of her fieldwork in Czech Television

Similarly but even more apparently, as Jacob and Lotte recalled, the attacks in Brussels in March 2016 disturbed the daily routine in Brussels newsrooms to the extent that the whole newsroom started organically to work on the same topic. The domestic and external affairs desks united; the people from the cultural and sport desks went to interview witnesses and families of the victims, so that political reporters could make the "hard news."

For some media researchers and journalists, it is precisely the disorganization, chaos, and anomia that create the intersection of inside-the-media and outside-the-media crisis, and what lies at the core of "crisis." Crisessituations in which a major change, decision-making time constraints, limited information, and uncertainty are coupled with threats to core values at the personal, group, or state levels - fundamentally challenge journalists' practices (Ben-Yehuda et al. 2013; Van Der Meer et al. 2016). Thus, as Olga said, crisis is a "moment threatening a standard state in which the journalist works. Any situation that poses significantly higher demands on the work that we do." 
A similar-organizational and professional—challenge is experienced by those who cover crisis events on the spot:

It's not only to get there, not only to arrange all the permissions, not only to approach all the people, make the report, write it, cut it, but I must also reserve some time to send it. Which is somewhat more stressful than in normal situations. (Tomáš)

Tomás hinted at technological difficulties related to making or sending a report. Indeed, sometimes these reached the level of a technologically induced "crisis." Tobiás recalled his experience of reporting the terror attack on Charlie Hebdo in Paris:

Speaking of technology, it was because of my photographer. Because I came to the hotel, wrote an article, and then he borrowed my computer (...) to send the photos. But while sending them, he switched something over and I couldn't start up the wifi at all. And now ... you know the deadline is approaching and you have to send it in 30 minutes, the wifi is not working, in an internet café you can't get to your professional email. ... (...) It was a crisis situation, but more a crisis for the people here [at the headquarters] than for me, but for me as well, a bit.

The crisis out there made the technological difficulties more likely-as Josef said,

In a crisis situation, you are more in a hurry, see, the technical equipment is more endangered, there are bigger problems with the signal, the internet connection (...), and the first thing the authorities do in riots is switch off mobile network operators, so you find yourself cut off from the newsroom, which makes your life quite complicated.

In this sense, the less technological equipment one works with and the lighter one travels, the less difficult her situation is. Not least because one cannot move around that easily with more objects than pen and paper (Judith). James instinctively touched his trouser pockets with his palms. Almost empty. Like many times before, he felt relieved and lightweight. A scribbler, as more loaded-down TV reporters used to call press people. He recalled Čestmír speaking about reporting on the Haiti earthquake: whenever his cameraman pointed a camera at the wounded and homeless, the 
latter felt much less comfortable, ${ }^{2}$ which, as he suggested, hindered him from doing his job. The same thing was experienced by Lotte, Ernest, and Tomáš, mainly in refugee camps across Southeast Europe, the Middle East, and North Africa. Moreover, as TV reporters, Čestmír, Josef, Sam, Carl, Vitek, and their cameramen had to go to the most affected-and still dangerous-places. "You have to shoot it. Because otherwise what? Otherwise you'd have a view from your hotel and an interview with a taxi driver" (Čestmír).

In turn, the technological crisis was equally traceable at the mediaorganizational level. James remembered two moments at $\check{C} T$ :

Main morning meeting. Evaluation. Obviously, there was a problem with broadcasting the breaking news on the Paris attacks. "We had a problem with the thematic bars, they didn't work for two hours!" Martin, the boss, discusses with the others how to deal with such a "crisis situation," and "how to prepare crisis management." Then, Martin concludes: "For the news, it's a tragedy." (Field notes)

Control room. Marie announces: "The Tomáš looks bad."—“How, bad?” someone asks. "He is not ready yet." [Tomáš, a correspondent from the Balkan route, has not sent his report.] — "Shit! Are you kidding? It's a part of the overview!"- - I know it, but the Macedonians obviously don't care," Marie says. (Field notes)

Furthermore, the organizational and related technological mishaps and breakdowns were connected to the broader context within which they occurred-mainly the economic and political aspects. Thus, press people (Louis, Astrid, and Richard) spoke of the crisis of the paper press being challenged by online news outlets, which causes organizational crisesfatal lack of personnel and insufficient resources to cover international affairs, including wars and conflicts. "When the Russian aeroplane crashed over Egypt," Richard from $L N$ told James on their way out to lunch,

I was alone in the newsroom. So I could cover it only briefly. And he [Richard's boss] came and told me to make it more balanced. [The boss told

${ }^{2}$ The masses of reporters invading the grieving community can indeed cause further stress and have psychological impact on survivors of crises. For example, Siri Thoresen et al.'s study of survivors of the terror attack at Utøya Island (Thoresen et al. 2014) associated negative experience with media participation with increased post-traumatic stress. 
me] that if it had been an American aeroplane, we would have filled four pages with it. But he didn't realize that it was caused by the personnel situation. (Field notes)

The same could happen in television, in case the tragedy happened in the middle of July when the TV station produces fewer programs and many people go on vacation:

When Russians started to ... be in Crimea, and then when the pro-Russian rebels shot down the $\mathrm{MH} 17$ above Ukraine, when almost no one and only one of the bosses was at work, I was here from $8 \mathrm{am}$ to $1 \mathrm{lpm}$, trying to make the staff work. This was a crisis. (Šimon)

The typical silly season, which recently has not been that silly, though. In the case of Ernest's and Cyril's workplace, a newsroom of one of the most read Slovak dailies, the lack of personnel was long-term and thus had more systematic and structural effects. The two journalists together constituted the whole of the foreign affairs news desk. Neither of them could afford to cover crises in the field, because only one person would be left in the newsroom.

In sum, Nicolas from $L S$, speaking to James shortly after the terrorist attacks in Brussels on 22 March 2016, described the interconnection of the organizational and personnel crisis, the crisis out there, the crisis of the press, and the economic crisis:

At the newspaper $L S$ at the beginning of the year 2000 , we were 110 . We are now 90 . So we lack. ... We lost 20 percent for economic reasons, but we also have the pressure of the economic crisis, and at the same moment, we have the fatigue of this war stress. So what did we get? We got burnout. And we got people that are just on medical treatment, who are ill. Why are they ill? They are ill at the same time because of the economic pressure, posteconomic crisis, because of the management that is more brutal, but at the same time, the coverage of crisis. And you just have to try to distinguish now what is due to the economic crisis- this happens in every newsroom in the world - and what is due to the new threat related to the kind of trauma you have within your work. It's not that easy. (Nicolas)

Nicolas' summary not only puts in a nutshell the interconnection of the outside-the-media and inside-the-media crises but also shows well some specifics of crisis reporters' precarity, that is, their existential, financial, 
and/or social insecurity, consisting in irregular and informal jobs, erratic work schedules, overwork, low levels of safety, and high risk-and implies how deeply the precarity is rooted in media and cultural production (e.g. De Peuter 2011; Hesmondhalgh and Baker 2011).

James glanced to the left. Through the glass door he could see the spot where he was waiting a while ago. Nicolas touched upon the issue that James had already given a thought: work-related traumas and personal crises.

\section{Crisis Outside Is Inside a Journalist}

It was not that easy, as Nicolas said, to understand where stress and traumas come from. Yet, it was equally difficult to distinguish between inner and outer crises.

Many journalists - mainly TV reporters - said that on-the-spot crisis reporting meant long-distance traveling, lengthy, "endless" business trips, working up to 18 or 20 hours a day (cf. Pedelty 1995). "One pushes oneself to the limit, several days in a row. (...) Reporting on an exhibition of rabbits does not bring one to such a state. Only reporting on an international crisis can do that," Matouš said. When Josef stated that "at the other TV channel, they promoted 'No sleep during working trips,"” James was taken aback. Tomás told a story of feeling the limits of his own body after his cameraman collapsed in Hungary during the heat wave in 2015, and Tomáš had to run eight kilometers with a ten-kilo camera on his shoulder, to shoot a milestone of the "refugee crisis." Sparkling with stories from the spot, he also recalled how he tried to report on the financial exploitation of refugees on the Balkan route by Serbian villagers: "They nearly smashed my face in when I was trying to shoot it with the little camcorder, so. And many other colleagues had the same problem" (Tomáš).

But the journalists experienced more kinds of dangers that followed from the commitment to witness, directly or vicariously, the suffering of other people:

And you really see so much suffering, and you know, you get to know a lot of people, and sometimes you stay in touch with people, for example when I meet Syrian refugees in one of the neighbouring countries, they keep informing me on their way to Europe and how it's working, especially on how it's not working. (Lotte) 
James noticed a weak weeping sound coming from around the corner, reminding him that he was just about to board a flight to a focal point of a catastrophe, an event that epitomized the fragility of life on Earth. Sure, this was true for any catastrophe; but this time it felt different. Ice-nine was potentially the most destructive matter that had ever been invented. Never had there been so much uncertainty over the nature and scope of a crisis.

Casting his eyes on his own endangerment would have been unbearable, so James looked outward and returned to his thoughts. Like the distinction between the outside- and inside-the-media crisis (see the previous section), the distinction between the psychological and the physiological crises, risks, and dangers, in which his colleagues found themselves, seemed unclear and sometimes even non-existent (see e.g. ScheperHughes and Lock 1987).

Some things "can get you" and trigger or resonate with a "personal crisis" (Ester), like

when you find out that ... right into the people visiting a concert in a club, where they have gone to have fun, someone starts to actually ... shoot. Out of the blue, and many people have no chance. It's just something that really gets you. (Matouš)

Matouš was speaking about the attacks in Bataclan, Paris, that occurred on Friday, 13 November 2015. Another journalist, X, admitted-insistently "off the record, but really off the record"-that terrorism, but also violent riots and conflicts, caused him panic attacks that he carefully dissociated as a "disease":

I do have it from watching ... whether or not the policemen have collided with them on Maidan, see? (...) But alcohol helps, I guess. Because it blunts your ... Look, I don't drink here, ok? But when you have, say, two glasses of wine in the evening, you may be able to sleep and you don't think about ... that tomorrow there will be something like that again, actually.

The journalist $\mathrm{Y}$ hinted at a similar thing on the way to another smoking break, accompanied by $\mathrm{Z}$ :

"The main thing is that the crisis event grows into a health crisis. I have a backpack full of pills," says $Y$, while motioning to his backpack. Indeed, full of something. Both $\mathrm{Y}$ and $\mathrm{Z}$ look serious-it seems that he is joking only partially. "But don't write it anywhere," says $\mathrm{Y}$, giving a saddened smile. (Field notes) 
James thought, what else would have X admitted if he had smoked?

$\mathrm{Y}$ was one of those who stayed in James' life even after they were no longer colleagues. They became friends-or something like that. They once went for a beer after work and ended up talking about French poststructuralists, which apparently happened to create an implicit alliance even before they knew "it" about each other. In the months and years that followed, they used to meet every now and then, holding existentialist conversations (that proved to be even more binding).

Apart from "having to be ready for getting yourself as a reporter into trauma" (Nicolas), journalists frequently encounter or interview people who are in much bigger trouble or trauma, which often places the former into moral dilemmas and quandaries (see Boltanski 1999; see the section "Moral Dilemmas and Guilt") and makes the lot even tougher. At the same time, the very experience of meeting people from outside the European "privileged bubble" often makes them realize that "Our particular emotional reactions to those situations are not as significant as that of the people who are genuinely moving through those conditions" (Farrukh). Face to face with their sources' bad deals, the reporters' trauma seems either vanishing in obscurity or absurd. Taken together, the experienced trauma, guilt, consciousness of one's self-pity, and sense of ludicrousness can create a vicious circle.

Perhaps because of its relative "insignificance," said Matouš, "stress is something that one is used to, that pumps you up, it's not that it immediately ruins you. It ruins you a bit later."

After passing through the thorough control of James' ID card and boarding pass at the boarding counter, our hero set foot on the zebra path to the backdoor steps. Going to San Lorenzo, he said to himself aloud. It immediately occurred to him that he must have seemed ridiculous to the young woman who was still two steps behind him. Everyone here was going either to San Lorenzo, or to one of the neighboring islands that were expected to be contaminated by the ice-nine very soon-long before their arrival. For a second, the nervousness he experienced was bodily again. He shivered, felt the urge to erupt into laughter, and jump, pull a face, or cry.

His mood again debased the distinction between psychological and (or even "versus") physiological categories. After all, most of his fellow journalists did not distinguish the two. Like Nicolas, working on the Panama Papers: "The problem is not to avoid the contract killer. The problem is to discuss it with your wife. And children." 
As Nicolas' words suggest, such an experience-the dialogue between personal and outer (lethal) crisis-follows directly from the "dual state" as actors and observers which journalists are expected to simultaneously maintain (Peters 2011; Tandoc and Takahashi 2016). Or, to put it more precisely, the reporters' lived experience proves that a reporter is an actoreven more inevitably and obviously when she finds herself in danger. For example, as Annabelle Sreberny (2011) argues, September 11 canceled the hierarchy of significance of journalists' inner psychological worlds and the actual dynamics of global state systems; the outside crisis and collective trauma merged with the interior shocks. The very notion of the "dual state" is thus based on the fallacious assumption that journalists are, because of their professional authority (which is, in turn, based on the objectivistic illusion of truth), able to step out from the world-albeit only with one foot—and to look at events from above-even though only with one eye. Journalists' actorship resides in the potential political implications of their action (Ben-Yehuda et al. 2013; Van Der Meer et al. 2016), but also in their roles as witnesses and victims.

An extreme level of active involvement was apparent among journalists covering suicide bombings in Brussels, the city where they lived:

I recall March 22, that day I was working in shock in the medical sense of the word, even. I didn't expect. ... Because as a journalist, of course, we are used to reporting the crises, that's even our [job description]. Wars, etcetera, etcetera. We're used to that. Then, suddenly, it happens in your own city. That's completely different. (Jacob)

The reporters' involvement went so far as to erase the distinctions between their professional and personal identities (Du Gay 1996; cf. Pedelty 1995). This was not without consequences for the particular kind of objectivity-as-a-practice (Carpentier and Trioen 2010; see the section "Professional Ideology and Its Critique") that they performed.

The issue of the interrelation of crisis "out there" and the personal crisis of a journalist formed the core of what the research questions address, and what will the chapter "The Emotional Experience of Crisis Reporters: The Journey" deal with in more detail: crisis reporters' emotional labor.

Before entering through the back door of the aircraft, James stopped for a moment and glanced at the four fighter jets passing diagonally across the sky. The young woman behind him frowned at him and pursed her lips, but then she lowered her eyes. Her face seemed familiar to James, but he 
could not place her. He passed by a flight attendant with dark hair tightly tied back, popped eyes, and grotesquely strained smile, and hid himself from the macabre masquerade on board.

\section{The Crisis Out There Is a Locally Lived Moment Is a Global State}

Anytime James was on a plane, he felt he had changed his territory, widened his realm. Here, he was on his own. He loved the intense feeling of being alive: putting himself on the line, betting on himself, isolating himself with his responsibility and power-leaving The Mo behind and going toward a shrouding mist which, in this particular outside-the-media crisis, was incomparably vaguer than ever before.

\section{Typologies of Crisis Moments}

At first glance, the outside-the-media crisis seemed to be an obvious thing. "Something went wrong in a big way," threw in Bob, the minimalist. According to more talkative Julian, Čestmír, or Ema, crisis is a rather unpredictable event that cuts across short- and long-term processes and causes a deviation in society from normality toward a very negative direction. Natural disasters, wars, conflicts, big leaks, terrorist attacks, "and the like" (Čestmír) - these were the most commonly mentioned crises. Some reporters were more concrete and gave the examples of terrorist attacks in Paris during the year 2015 and Brussels in March 2016, parts of the Russian-Ukrainian conflict, the failed states in Egypt, Syria, and across Central Africa, the earthquake in Haiti, and "too many refugees in such a short period of time" (Tomáš). What all these understandings of the concept of "crisis" have in common is that they stress the temporally and spatially limited character and negativity of the event or situation. Most of all, they resemble the somewhat narrow definition of crisis as a more or less unpredictable event with potentially negative effects on its environment/surroundings/milieu - a turning point, a threat (Coombs 2010; Walaski 2011). As mentioned earlier, such a sudden and unpredictable event may also pose a danger to society and create high levels of confusion, as well as time pressure (see the section "Inside-the-Media Is Outside-theMedia Crisis").

Imagining the ice-nine-caused catastrophe, James finally found his seat. It was the same as the last time.

Although crises are "always about the people" (Marie, Lotte) and, being aware that it is them who make sense of the particular event and 
who structure the unknown (Weick 1995), the journalists always try to give the most truthful representation of what happened even more than in "normal" times (Kryštof, Sven, Cyril), each crisis is different "depending on the time when it happens and the place where it happens" (Olga).

each of them requires a slightly different approach, different preparations, different type of behaviour, different style of reporting. (Čestmír)

Thus, as Olga suggests, from the journalistic point of view, it makes more sense to distinguish crises based on their temporality and spatiality then based on their origin and nature (e.g. Cottle 2009; Sellnow and Seeger 2013). Most accurately, Nord and Strömbäck (2003: 71) suggest that there are four types of crises based on their predictability, the surprising character of the crises, and their newness or repetition: new and surprising events, new but expected events, surprising events that have happened before, and expected events that have happened before. The individual types are distinct in terms of the media representation of the given event. Indeed, the reporters say that they work differently with short- and long-term situations; with events that happen in the morning, at noon, in the evening; or during working hours and weekends; whether it happens in a neighboring country or in, say, Pakistan, Yemen, Nigeria:

when in Sana'a a bomb explodes at a market place and kills fifteen people, it has no chance to get anywhere. It would have to be 450 people and a children's choir, ideally. ... These shifts, it's called 'Arabic numbering.' When Europeans die, then it takes less.... Well, it's terrible. (Astrid)

Also Farrukh, Ida, Tobiáš, at least four women from $\check{C} T$, Ben, Sven, Ernest, and others in one way or another reflected upon the disproportion in the viewing of culturally close and distant deaths. By evaluating such an approach as "terrible" and "cynical," they implicitly-often by the way or on the way out to lunch (Field notes) - criticized news values of bad news, magnitude, relevance, and the power elite (Harcup and O'Neill 2001). At the same time, by expressing their criticism by the way and outside the newsroom, most of the reporters proved their adaptation to the somewhat bloodthirsty mainstream media logic: it was just the normal way it goes. 
Farrukh, pointing at "the grossest exploitation of dead black bodies" and talking about the camera as a weapon of "European Western power, let's be clear about that," pronounced more thought-through criticism. He partly evaded the iron cage of the Western mainstream media logic by going independent and working on stories that "standard magazines wouldn't buy." (An act which he could afford after reaching a certain level of fame and after collecting a number of awards for his work for Western mainstream media.) Similarly, for Ida, the very negotiation of geographical-emotional closeness/distance relative to enough corpses was sufficient as a reason to explain why she was uncertain about her future journalistic career:

I don't want to get to the stage where I won't consider fifty dead in Afghanistan sad. To be so ground down that I won't care. ... I want to keep the feeling that all human lives have the same value.

Both of them deliberately refused to accept that crisis events and tragic stories are more newsworthy if they refer to elite people, elite nations, and to culturally close regions (see Harcup and O'Neill 2001), and adapted/ were ready to adapt their biographies accordingly.

For the rest, the "twenty bits" (meaning "casualties") in, say, Baghdad, according to Tobiás, had to stay in the zone of detachment, unlike for example Charlie Hebdo, "because taking all these attacks like [one takes] Charlie Hebdo, one'd go nuts." "It's impossible to carry all the weight of the world on our shoulders," Kryštof summed up.

James wondered whether the specific combinations of newness and repetition had also some consequences for journalists' emotional engagement in the event. Did they react to (potential) death with laughter or with explicit resistance to insensitivity only because they were caught unawares? Was a surprising event necessarily also more emotionally shocking? Is it possible to get emotionally used to a long-term crisis? Can good preparation reduce the stress?

\section{Belgium, Czechia, and the Closeness of a Crisis}

The grasp of the contact between Europe and the Global South was not the only important aspect of the spatiality of crises. The European mediascape comprised miscellaneous regions. James knew at least something about the varied European media systems (while working mainly in two of them), each of them dealing with specific challenges. 
There was Belgium: Belgique, België, and Belgien. Some of the Belgian journalists talked about an inherently critical context of their work, stemming from the reoccurring conflict between Wallonia and Flanders:

Belgium is not a particularly ... peaceful land. We are not fighting. But ... crisis has always been there. The differences between the two communities fuel a rampant crisis. (Louis)

Moreover, the Belgian reporters had a somewhat specific experience with covering a major crisis event-a terrorist attack - that happened in their own country. "War, it's not just going on there. It's just coming back here," said Sam. The difference from "just another bombing" over there (Lotte) and when "the crisis came home" (Jacob) resided in its "surrealism": an internationally relevant negative event that the reporters were accustomed to reporting on from afar suddenly occurred in their own country. Finding themselves in the middle of the type of event that they had previously experienced as temporary visitors, they had difficulty realizing, or at least found it "very strange," that it was happening in Brussels:

So I was invited by $C N N$ twice, and that was a very strange experience. Because then it's kind of surreal. Because this is a place where I often go.... It really felt strange to talk about your own country as a ... Because the questions were really like a bit combat zone questions. (Sven)

Sven's statement illustrates his feeling of the unusual nature of the double status as both an observer and a member-even spokesperson-of the community (Peters 2011; Tandoc and Takahashi 2016). His (and others') "surreal" feelings and thus emotional difficulty were determined by several dimensions of closeness at play (Tumber 2011), mainly by the materiality of the situation and its technological circumstances and by the fact that it affected loved ones and fellow citizens, about whom the reporters were worried.

First, the usual experience of crisis reporting was altered by the materiality - the geographical and technological circumstances - of the situation. The space where the reporters commonly performed their work merged with a meaningful, personally relevant place:

The problem is that the airport was always for me a bit like a homecoming. That airport. Because it's mostly my starting point and the end of my journey. ... You see a lot of misery, but when you come to the airport, you feel safe, home, secure, you know? (Carl) 
Moreover, the reporters' sense of existence was intensified and confused by technology. Carl further recalled that the first night after the allday reporting from Zaventem Airport, he went to his favorite bar for pilots and flight attendants not far from the spot:

And the TV was playing. ... That was already strange. Because you were seeing yourself reporting on a place which was only half a mile away, [and] you were still there. ... So it was like becoming all one.

Other journalists, besides reporting on the attacks, became objects of others' reporting, which disturbed the outer boundaries of the profession (see Carlson and Lewis 2015). Sven turned into a talking head (see earlier in the chapter). Ben was helping US journalists find their way around Molenbeek, a neighborhood where he and the perpetrators lived. This experience of convergence seemed to reach an uncanny extent which appeared to transcend reality.

Second, for the interviewees, the difference resided in their emotional closeness to people who were directly or indirectly affected, such as children, friends, parents, siblings, and their perceptions:

it's very different, because I have a family and I have two children who go to school in Brussels, so my son was here, my little daughter just had a school trip, a tour of Brussels, and the whole school was actually in the metro. (Sven)

And then there comes an e-mail from the school, it says 'everything is ok, but children can't go out during the [recess], so they have to stay in.' ... So that's, of course, that's very emotional. (Jacob)

All of the journalists were also well aware of their active role in the construction of narratives about the attacks, the perpetrators, and the victims, and thus of their political authority within the community. Moreover, they were well aware of the construction mechanisms used by terrorist organizations via various media (e.g. Falkheimer and Olsson 2015). Finding themselves in the middle of the struggle among narratives meant that their incentive to produce the best possible news (McDonald and Lawrence 2004) further resonated with the emotions they felt as Belgian citizens and inhabitants of Brussels. For example, Sven and Sam were frustrated when their analytical accounts were misinterpreted or misunderstood: 
It's like a puzzle. Many pieces of the puzzle, as many as you can, different angles, different views. What is affecting me, or touching me, is when ... they don't treat it with proper respect. ... I was anxious. Society has divided. You have Islamophobia, so I think it's extreme. ... A war zone, even for me, is less tiring than that. Because this is part of my own society. (Sam)

Both the social and the material dimensions of closeness and identification constituted membership in the imagined community of Brusselians/ Belgians sharing the trauma and the not-so-imagined community of family members and neighbors (Anderson 1991; Hutchison and Bleiker 2008). The combination of the material context and social ties thus significantly intensified the surreal duality of the journalists' status as observers and as community members (Peters 2011; Tandoc and Takahashi 2016) while simultaneously triggering bodily feelings of fear, worry, and anger. To put it differently, the closeness challenged the border between the reporters' personal and professional identities. Since the identity of (media) professionals constitutes itself in relation to personal identity (Du Gay 1996), their socio-materially mediated integration raised questions about the journalists' fit within professional boundaries (Carlson and Lewis 2015).

Interestingly, some Belgian reporters were not astonished and talked instead about confirmation of their predictions, or even spoke about "release of tension" in their Brussels newsrooms.

To my surprise, people were really ... I wouldn't say satisfied, I'd say eased, because what we were feeling for years just happened. And we knew what exactly the form that it took was. ... It just concretely happened, and you just said, 'Uff, okay. So we work.' (Nicolas)

After the long-term vague and constant threat and anxiety were condensed into a concrete attack, the journalists found relief in the clear task that had landed in the newsroom.

In sum, reporting on a crisis close to home ultimately resulted in the journalists' stronger identification and closeness (cf. Tumber 2011), as the latter constituted "surreal" feelings related to the ambiguous and selfcontradictory relationship between professional and personal contexts and identities (Alsup 2005; Peters 2011; Tandoc and Takahashi 2016; Van Zoonen 1998). On the one hand, their tasks placed the reporters in an emotionally demanding position and required much effort. On the other 
hand, the tasks needed to be performed despite the emotional thrill of the moment. Thus, the work itself forced (or helped) the reporters to avoid fully realizing the tragedy and to suspend their feelings.

Nevertheless, even an emotionally shocking event of this kind did not come completely from out of the blue. A mere week before the attacks on 22 March 2016, Louis anticipated:

We are confronted with the fact that it could also happen here in Brussels. Yes. Now, this is maybe the most difficult thing to accept. Because we've got to live with this threat. This is maybe a new paradigm. (Louis)

The recollection of Louis' prediction gave James the shivers. However, what gave him the shivers in the blink of an eye were the Czech specifics of covering crises.

Czechia used to be a very calm place. In a way, it was isolated in its homogeneity and lack of (media) interest in foreign affairs (Vítek, Josef). No crisis on the horizon; so some journalists had the feeling that they needed to create one.

Like on an especially silly seasoned day in June 2015, after doctors suppressed the MERS (Middle East respiratory syndrome) virus. Marek, head of one of the newsrooms, being nervous about the lack of breaking news, was marching around the newsroom, jokingly ordering his subordinates: "We need another disease today, come up with another one!" (Field notes). The feeling of the need for a crisis was reduced to absurdity by one of the commercial TV channels. In autumn 2015, its management expressly ordered the staff to report on refugees as a threat (The Economist 2016). The strategy of such a purposive, deliberate, and literary securitization of migration (e.g. Bigo 2002), or rather institutionalized xenophobia, broke all ethical standards. Not only the action of the management of the TV channel, but also other processes of building a security threat from nothing was harshly criticized by many colleagues of James (not only from Czechia), such as Astrid, Tobiáš, Richard, Čestmír, Josef, Ema, Ernest, Giuseppe, Bob, and Diego.

Such creation of artificial, sensational news emerged partly from another specific of the Czech media system. Many times James had been told and made aware that the Czech post-socialist media environment was "distorted and deviated" (Matouš), fatally marked by the "wild privatisation" after 1989, oligarchization, and the neoliberalist turn (manifesting itself, among other things, in the opinion that public service media are 
superfluous, and by the lack of media attention paid to foreign affairs) (see Balčytienè et al. 2015; Örnebring 2009). As such, the Czech media system was seen as inherently critical as well, by both paper press journalists and public service TV reporters, in particular, because the nature of the national media system was seriously affecting the quality of journalism:

In this country-when I leave aside the economic aspect—-this [media ownership and political influence] is a much bigger crisis. That many really important topics do not appear in the media. Which is simply really dangerous for the society. (...) And the truth is that a lot of journalists are bribed. (...) Now, switch it off-really. (Y)

James did not know what to switch off, but cared rather about his vanishing naiveté. Even now, when he recalled the moment, he saw his gullibility fading into the distance of front rows. To James, this conversation worked as an initiation ritual. As if the information was labeled "staff only," similar to the warning sign he had spotted some minutes before inside the tail next to the uncanny flight attendant.

To put it in a nutshell, both the media systems suffered from nationally specific defects. Each of them had its own way of being inherently critical.

Importantly, a terror attack in one's own country or inventing a threat is not the only way how a crisis can come closer. It can also get closer, for example, by language. Kate Adie, a reporter covering Northern Ireland, recalled that threats issued in her own language were far more frightening than threats delivered in a foreign language by people who look different (Tumber 2006). Likewise, Sven recalled that it was "too much" when, a few days after the Brussels attacks, he was asked to write an article about the first Belgian Daesh fighter who killed somebody execution-style, and he needed to watch the Daesh video:

I mean, it's a horror, it's horrible. And then I watched it, and that felt like the information was too much.... Of course, it was the killing of the person, but also. ... Originally, I am from Antwerp. It was also his accent. ... The accent of my schoolmates.

By sharing the accent with the perpetrator, the crisis came unbearably close to Sven. By comparison, Lilah, reporting on refugees and speaking Arabic, grew closer to the victims of the "refugee crisis": she became the medium between refugees and audiences, and even European offices, in yet another sense. 
A level of closeness stemmed also from the journalists' professional ecosystem (Abbott 2005). For example, after the murder of Slovak journalist Ján Kuciak and his fiancé Martina Kušnírová, James' colleagues from Slovakia perceived a certain determination and interconnection among the community of journalists-mainly the investigative reporters. The sentiments raised by recent attacks on journalists could even transcend national borders. Indeed, journalists often felt themselves as members of a transnational mediascape that transcends all borders, rather than as employees, falsely self-employed or contractors of a particular media company and working in a particular country. This included also fixers-often local journalists or activists - who sometimes found themselves much more endangered than the European reporters, and for whom the reporters felt responsible (Gloria, Ernest, Sam). The most evident case of the professional unity was the terror attacks on the staff of Charlie Hebdo:

I mean, the Charlie attacks were also ... felt harder here in the newsroom, because it was colleagues. Then it comes closer. ... I think that Charlie had a deeper impact on the professional things we do here than the other Paris attack, which ... Charlie was just an attack on people like us. (Jacob)

Jacob expressed the sentiments of many of his colleagues from all around Europe. The unprecedented nature of the Charlie attacks was also apparent in the newsrooms where James worked. He took out his cell phone and scrolled through the gallery. He found a picture of a column behind which he used to sit when he worked at $L N$.

On the best visible side of the column, above a notice board of the foreign news desk, there was hanging the iconic green title page of Charlie Hebdo with Mohammed holding "Je Suis Charlie" sign. On the square, someone pasted an even bigger black poster with Mohammed's caricature.

He scrolled down a bit more and ran into another photo from one of the labyrinthine corridors of $\check{C} T$. It depicted a door that he used to pass several times a day. On the door, there hung a photo of one of his distant colleagues, saying "Je suis Jiřrı." The second picture made him laughgood old times!

\section{Individual Tragedies Within the Broader Picture}

Making fun of the Charlie Hebdo case did not necessarily mean that the reporters were wicked and unsympathetic (see how crisis reporters defend themselves from constantly facing others' suffering in the section "Coping 
Strategies"). Quite the opposite: for many of James' colleagues, crisis is defined primarily by the death or suffering of people. For example, to Sven, a political crisis, a natural disaster, and a social crisis were only words referring to the prelude to "crisis as a situation where human beings end up in a very vulnerable and dangerous and harmful situation" (Sven). Such an understanding of crisis paved the way to rich storytelling: "I try to pick out a human story to tell the broader political view," Lotte said. Judith even believed that putting the human story into context forms the core of "valuable journalism" and an answer to her students' question: How not to feel as a vulture?

Correspondingly, the level of crisis-ness consists in the nature and context of the event. Crisis must have "a wider societal impact" (Tomáš). The crisis-ness of an airplane crash, for example, depends on whether (the media have known from the beginning that) it was a terror attack (and acted accordingly - gave it much more space) or not. A single terror attack, a local conflict, or an environmental catastrophe epitomizes a broader dramatic story of modernity (Heaphy 2007; Wagner 1994), and the task of a crisis reporter is to show the relation of the two. In turn, for Sam, as for Vítek, Jacob, Sven, Josef, and Lotte, connecting the immediate, local level with the long-lasting, global, "broader picture" (Lotte) was the source of their passion for crisis reporting. "It has to be rooted in complex societal evolution. And then it's interesting," Sam said.

James put his hand into his pocket, pulled out an almost finished pack of chewing gum, and stuck the last piece in his mouth, trying to protect his middle-ear micro-mechanics against the air pressure. The aircraft was supposed to take off in a few minutes.

The link between the contemporary crisis of modernity/risk society (Beck 1992; Giddens 1991; Wagner 1994) and locally and individually experienced crisis situations has been thoroughly theorized. As Anthony Giddens argues while speaking about global threats, most notably the latest fads of the industrialization of war, these

social circumstances are not separate from personal life, nor are they just an external environment for them. ... Changes in intimate aspects of personal life, in other words, are directly tied to the establishment of social connections of very wide scope. ... The wholesale penetration of abstract systems into daily life creates risks which the individual is not well placed to confront. ... Greater interdependence, up to and including globally interdependent systems, means greater vulnerability when untoward events occur that affect those systems as a whole. (Giddens 1991: 12, 32, 136) 
Similarly, Ulrich Beck and Elisabeth Beck-Gernsheim note that

social crisis phenomena such as structural unemployment can be shifted as a burden of risk onto the shoulders of individuals. Social problems can be directly turned into psychological dispositions: into guilt feelings, anxieties, conflicts and neuroses. (Beck and Beck-Gernsheim 2001: 24)

All the global threats/risks thus become localized and materialized in the emotional lives of individuals, who then feel anxious. Highconsequence risks especially shake the foundations of ontological security, the basic secure sense of reality and continuity (Giddens 1991), which influences the capacity of individuals to deal with existential questions. To be sure, as Giddens stresses, the point is not that everyday life is more risky than before; rather, the risk climate means that thinking in terms of risk is everyone's ever-present exercise. Thus, many neuroses and anxieties emerge as a response to risks and threats and their biographization-that is, their incorporation into individual biographies (Beck and BeckGernsheim 2001). In other words, although individuals may be required to resolve the potential neuroses and anxieties on their own, perhaps with biomedical help, these are individualized and psychiatrized social changes and systemic problems (Heaphy 2007; Lasch 1991; Scheper-Hughes and Lock 1987).

James' colleagues were aware of this dialectic in the case of their respondents, talking heads, interviewees-in short, the unfortunates, among whom the journalists were rather spectators or interlopers (Boltanski 1999). Like Lotte, speaking about Syrian children in Turkish refugee camps:

But you just know that this generation is so damaged because of what's happening now. That it's not good for the future either. And that's just why it frustrates me so much. Because it's not just happening now, it will have consequences for at least one and probably two, three generations. (Lotte)

Nevertheless, the dialectic of global and locally lived crisis is relevant also for the "crisis reporters" themselves. For them, the generalized crisis of modernity (see later in the chapter) goes hand in hand with the everyday contact with its real, "already destructive consequences" (Beck 1992: 33; see the following section "Crisis is Media-Constructed Is Real") such as floods, limited wars, and terror attacks, which together lead their individualized psychological consequences on a leash. 
James looked out the window. In the distance, he saw the last passengers of a just-landed flight striding into the airport building. A tall, slim man was leading two little children by the hands. Nostalgia for his father overwhelmed him-his childish sense of humor; silent conspiratorial bursts of laughter; his huge warm, dry, lined palms that he used to put on anthills when James was a little boy; ants would climb up his hands-the swarming astonished James; and his habit of shaking the walnut tree in the garden, so that James could pick up the nuts. It was more than a year since his father passed away.

Losing him led James into an even greater need for independence. And, here he was: ready to make good use of it. Although the pain was still stabbing.

In the newsrooms, the response to situations of mass death and suffering that implicitly reminded the staff of the potential destruction of the whole planet was often humorous (see the section "Cynics and Kynics: Pissing Against the Idealist Wind"). James soon learned the "typical morning joke" that journalists say to each other after entering the newsroom: "No airplane crash yet today?" (Olga).

An airplane crash was something that James really did not want to think of at the moment. His will to life was too strong. It made itself heard: his stomach rumbled.

The World and Journalism After September 11, 2008, 2011, 2014, 2015, and 1750

Rather, James recalled another situation from the $L N$ newsroom that made him laugh:

Searching for something at The Independent. After clicking on a headline, a stereotypically Arabic melody wafts through the open space. The entire editorial staff immediately stops working, falls silent, stands still and starts staring at me. I apologize, shrug my shoulders and have to start laughing. "Since Charlie Hebdo, everyone gets afraid when they hear something like this in the newsroom," an editor, scared stiff three meters away from me, explains. "Is it your ringtone?" I say, "No, it's started to play at The Independent." Then he starts joking with the colleagues: "Guys, let everything be, we're gonna have a moment of prayer!" (Field notes)

Many of the crisis reporters talked about the contemporary changing, complex, non-stable world. As a turning point, they usually cited 
September $11-$ a day that shook to its foundations the familiar notions of how best to practice journalism and what it means to be a journalist (Zelizer and Allan 2011). A milestone after which international reporting became more important, because the West realized that even distant conflicts can have impact (Anthony). Some of them saw as another milestone the so-called Arab Spring in 2011 (mainly for journalists specialized in the Middle East), the beginning of the Russian-Ukrainian war in 2014, and the aforementioned attack on Charlie Hebdo in 2015. In their view, shortterm crises were interconnected with failing states, the population explosion, or lack of resources. As focal points, they saw the MENA (Middle East and North Africa) region and the "unclear zone between Russia and the rest of the world" (Josef). Jacob and Josef thought that

It's a kind of avalanche of crisis that we've seen and still see. It started in 2008 with the bank crisis, and it hasn't stopped since then. ... professionally, it's very attractive, to try to analyze these big movements, the financial crisis, the migration crisis, the institutional crisis with different instruments, so that's intellectually very attractive- that's the reason why I am a journalist. On the other hand, of course there is the terror crisis. (Jacob)

the relatively stable state is more and more relative and the crisis is kind of permanent. (Josef)

The fast pace of change is also reflected in media practices and required journalistic skills. While "15 years ago we needed a war correspondent, now we need an expert on terror, and the next generation will need geeks," said Nicolas.

James pulled his computer out of his backpack and smiled faintly at his relative technological incompetence. Interested in analytical work, he was not a geek and never wanted to be. So far, he had managed to disguise his reluctance and a kind of technological conservatism that he self-legitimized as romanticism. But if Nicolas was right, James knew he would need to find another job in a few years.

This understanding of permanent crisis is fully consistent with the way of using the concept of crisis from the second half of the eighteenth century onward: as a word describing a generalized modern experience, to the extent that it becomes a permanent concept of history. "The concept of crisis has become the fundamental mode of interpreting historical time. (... 'Crisis' becomes a structural signature of modernity. ... an immanent, 
permanent condition of the world" (Koselleck 2006: 371-372). And since then-thanks to Rousseau, Diderot, Paine, and Herder-the term has gained a religious connotation akin to the "Apocalypse" and "Last Judgement"; albeit used in a post-theological mode, history has incorporated eschatology. Periods of exception and crisis have become the norm (Agamben 2005 in Kaleta 2017); also reporters have normalized the abnormal and routinized the absurd and extraordinary (Pedelty 1995; Zelizer and Allan 2011).

"In the unlikely event of landing on water" James listened to the metallic voice casually wafting from the loudspeakers. The theatrical flight attendant was performing the robotic dance on emergency exits.

The generalized crisis of modernity has been widely discussed by the sociological successors of the dark-minded enlightened philosophers. Although, as stated earlier, the word "crisis" itself is not favored by the social theorists of late modernity for its excessive use and vulgarization, Peter Wagner proposes to keep it to describe periods of modernity "when individuals and groups change their social practices to such an extent that major social institutions and, with them, the prevailing configuration of institutions undergo a transformation" (Wagner 1994: 31)-in other words, for periods of de-conventionalization tendencies ( $\mathrm{cf}$. the positioning of crisis versus "normal times" by McDonald and Lawrence 2004, or Schudson 2011) accompanied by lack of integration, a sense of decline, rupture, or ending. Others, such as Ulrich Beck (1992) and Anthony Giddens (1990), characterize the late/reflexively modern world as a place full of globalized, universalized, and vague threats where people live in a state of permanent endangerment and loss of ontological security (Beck et al. 1994). The most current eschatological vision that they put forward thus consists in the "heightened sense of 'man- made' risks that cut across old boundaries of class, generation, geographical location and the like" (Heaphy 2007: 9) and in the view that "Modernity is self-critical and selfdestructive" (Touraine 1995: 100).

Which is not inaccurate. Although James was too young to be able to compare the level of today's crisis-ness with premodern periods, he would agree with Giddens that there were some new trends. "The possibility of nuclear war, ecological calamity, uncontainable population explosion, the collapse of global economic exchange, and other potential global catastrophes provide an unnerving horizon of dangers for everyone" (Giddens 1990: 125). Similarly, Beck draws attention to the continuous threat of environmental and technological risks accompanying the attempts to 
increase and utilize Western techno-scientific rationality (that has been believed to help with overcoming the risks emerging from prior modernization; mainly poverty, social stratification, and unemployment). As a consequence of these attempts to deal with the risks of early modernization, catastrophe becomes an inseparable part of the "second" or late modernity (Beck 1992). The risks are multidimensional: the environmental and technological threats are inseparable from those of a social, economic, or political nature (Beck et al. 1994).

The case of San Lorenzo was emblematic. It was simply impossible to delimit the disaster caused by ice-nine as an event affecting-but also caused by-one particular "material." Above all, as ice-nine was a scientific invention, the catastrophe was nothing but an extremely concentrated outcome of modern thought (see Van Loon 2002) (Image 2.3).

The spreading of ice-nine, like other individual crisis events, then, can be seen as a spatially and temporally limited realization of new risks. This definition emphasizes, first, the real aspect of new risks, and sidelines the potential and unreal ones (Beck 1992), and second, the dialectics between the contemporary crisis of modernity, or risk society, or reflexive

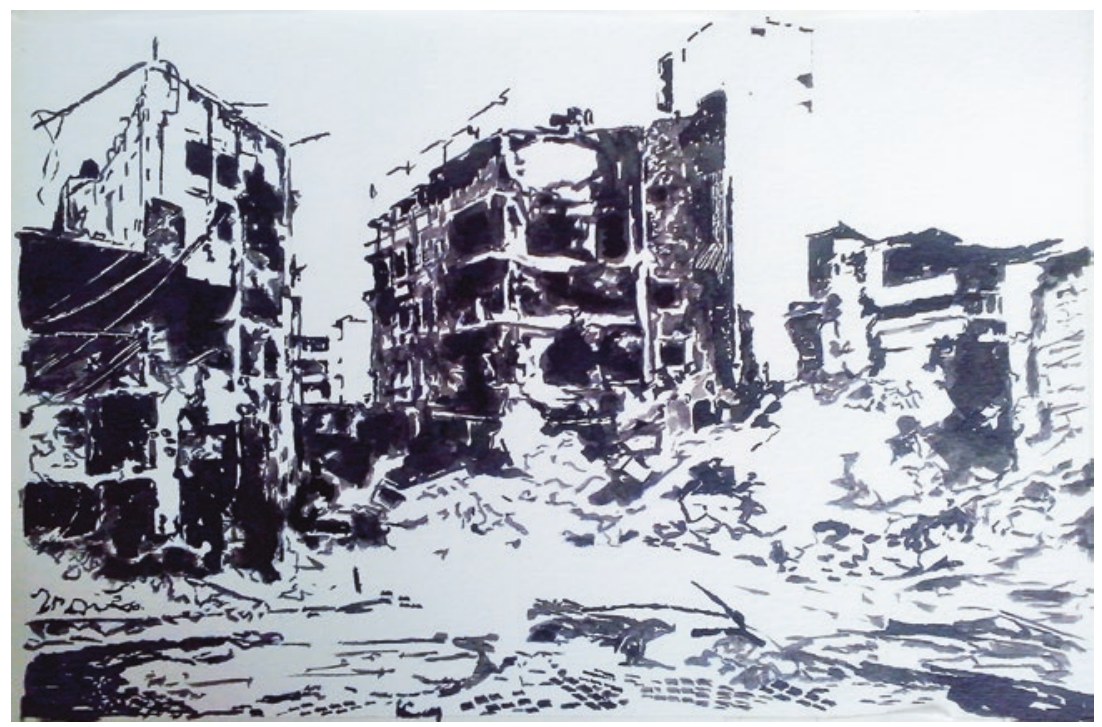

Image 2.3 A frozen city. Drawing by Peter Van Goethem, 2017. Courtesy of the artist 
modernity (Beck 1992; Giddens 1991; Wagner 1994) and locally lived crisis situations.

While putting his worn carry-on suitcase into overhead storage, James saw her face. The young woman who had always been two steps behind him was now sitting right in front of him. No doubt it was her. Sophie Schlesinger, the crisis reporter. He had seen her yesterday on TV while watching the first flashes on the San Lorenzo catastrophe.

In crisis reporting, women were either not visible enough or were too visible, depending on the level and face of patriarchy permeating the social context. "Crisis reporting is generally considered a male job," his Italian colleague Giuseppe explained. But Sophie seemed to be everywhere. At the same time, she stood out among the other "little girls in bullet proof vests"-young female celebrity war reporters criticized by Bob for contributing to the spectacularization of Danish crisis reporting-by her erudition. She was always equipped with thorough knowledge of the context. Taken together, it gave the impression that she was gifted by some preternatural capabilities.

In fact, it was she who inspired James not only to become a journalist, but, which is crucial, to try to do his best. But most importantly-and this was something that James did not realize-her somewhat moral and responsible approach to the profession was what kept alive James' hope for the existence of some basic values and principles. And now, she was sitting here, toughing it out.

\section{Crisis Is Media-Constructed Is Real}

The risks Beck talks about are rather global, vague, invisible, allembracing. Yet-although Beck and his followers emphasize the "notyet-event" (Beck 1992: 33) and the "potential" character of new risks - the plastic soup, the fall of $\mathrm{MH17}$, the BP oil leak in the Gulf, sinking islands, or the Fukushima nuclear catastrophe are painfully localized and affect the everyday life of many people (e.g. Allan et al. 2000). Beck himself states that

Risks of course do not exhaust themselves in the effects and damages that have already occurred. There must be a distinction between already destructive consequences and the potential element of risks. (...) In a fundamental sense they are both real and unreal. On the one hand, many hazards and damages are already real today: polluted and dying bodies of 
water, the destruction of the forest, new types of disease, and so on. On the other hand, the actual social impetus of risks lies in the projected dangers of the future. (Beck 1992: 33-34; italics original)

James looked at his mobile for the last time before selecting flight mode. He opened Signal, recommended for internal communication. A message from Fred: "Good opportunity," Fred wrote. "Don't screw it up." The whole management of The $M o$, as with other media organizations James knew, and maybe even for the media in general, had a somewhat love-hate relationship with crisis events. Mainly love:

When there is an international crisis or something happens, like Haiti, one doesn't tell oneself, this is crisis, but rather simply, this is an event! (Astrid)

There seems to be a tendency towards more conflict reporting. (...) And there is always the element of crisis. (Jacob)

This means that-somewhat contrarily to the aforementioned definition of crisis - it is not only the inherent characteristics of an event that constitute crisis-ness, negativity, and thus newsworthiness (Harcup nad O'Neill 2001). The crisis-media entanglement also works the other way around: media can define, sensationalize, deny, or hide crises (Cottle 2009; see the section "Emotions in Crisis Coverage"). "What is worth covering is decided at the meetings" (Josef). The newswork and the process of becoming of a crisis overlap. For some, crisis is even defined by the visual form it takes on the screen: "It's me, who decides, this is a crisis, and puts there the yellow banner," said Olga once, as if it was taken for granted.

In general, it can be said that modernity and its crises have always been inseparable from their media representation: the birth and development of modern institutions have been bound up with the increase in mediation of experience by printed text and, subsequently, by electronic signal, nullifying spatial-temporal distantiation, emptying time and space. "Intrusion of distant events into everyday consciousness" (Giddens 1991: 27), together with the nomadic nature of life spent in trains, cars, and airplanes, and then on the Internet (Beck and Beck-Gernsheim 2001), has been one of the major defining features of (late) modernity. Media, evoking the sense of reality inversion, have blurred the boundaries between "real" events and their representations. Expert knowledge and abstract systems have 
become accessible to lay actors, introducing to them the risks and the new forms of danger they have to accept.

In particular, invisible risks "initially only exist in terms of the (scientific or anti-scientific) knowledge about them. They can thus be changed, magnified, dramatized, or minimized within knowledge, and to that extent they are particularly open to social definition and construction. Hence the mass media and the scientific and legal professions in charge of defining risks become key social and political positions" (Beck 1992: 23; italics original). As the risks are self-fulfilling by definition and have been coconstructed, spread, and shared via sharing reflexive knowledge and communication technologies, the (news) media can be understood as a risk-constitutive force: "media are part of the technological constellation through which risks come into existence" (Van Loon 2002: 12; see also Cottle 2009). This is what Sam meant when he spoke about today's Europe and the Middle East:

you have the wars in the Middle East, you have the terrorism which is happening here, and the extremism, and Turkey and the migration. And all these three are linked together. You cannot solve one without solving the others. But what is happening in the media, in the minds of the people, is that they isolate one of the three and give a very strong aggressive answer to it. ... You cannot solve one without solving all the three of them.... I think the responsibility of media and politicians in these days is so enormous, to keep our society from slipping into times like before.

Although Beck explicitly emphasized the socially constructed (i.e. media-defined) character of new risks, the subtheme of media influence remained under-theorized in his work (Allan et al. 2000; Cottle 1998; Tulloch and Lupton 2001). Later, Beck himself acknowledged the insufficient attention he had paid to the media, given their importance in the risk society:

the key significance of mass media in the risk society (...) is something I have addressed again and again, if only with bold theories (...). This is clearly not sufficient given the significance of the subject and is to be attributed to my limitations alone. For the risk society can be grasped theoretically, empirically and politically only if one starts from the premise that it is always also a knowledge, media and information society at the same time. (Beck 2000: xiii-xiv) 
Nevertheless, it was not only his work but sociological and anthropological research in general that has paid surprisingly little attention to the role of the media within the process of defining and constructing new risks and the crises that arise from them (Allan et al. 2000; Tulloch and Lupton 2001; Van Loon 2002).

"Do you mean the second live update and the third one?" James heard Sophie Schlesinger talking to somebody, maybe a shift leader, on the phone, scheduling the dosage of the San Lorenzo catastrophe. Probably the last chance to plan live broadcast before taking off. Her voice was much softer, calmer, thoughtful, and more tired than he had imagined.

The reporters and journalists were well aware how much of an active role they played in construction of crises. Like Ema, who complained about the relationship between media routines and the way of handling the "refugee crisis" in Calais:

Our correspondent is on vacation. ... We thought, no hurry, it had already been happening for a few days. Nevertheless, yesterday, iDNES published the news. And this is the moment when the crisis situation is created a bit artificially. ... This is the moment when the crisis situation emerges from the competition. Before, it wasn't a crisis, in my opinion. It was a phenomenon that was already continuously happening. But in this way, it was turned into a crisis; suddenly six people simultaneously got engaged in it, discussing who will fly there first. (Ema)

Once a crisis is constructed, the reporters and media organizations know they have gotten involved in its politics as well; therefore, the Flemish national public service broadcaster even employed an official policy of "constructiveness." To be "constructive" meant to avoid spreading fear and firing up emotions by "trying to explain ... why something didn't go right, apparently, ... without, of course, ignoring the facts, even if these facts are inconvenient" (Jacob).

Such a constructiveness, officially proclaimed or not, was considered a principle of public service media in general. A moment that partially exemplifies it happened at $\check{C} T$ :

Afternoon meeting. Discussing today's action of a host in the studio. Her guest, a military psychologist, interconnecting the Paris attacks with migration in his speech, said that radicalization of Muslims was genetically encoded. The host was apparently shocked: she opposed him and said, 
"Let's talk about something else." Nevertheless, she was criticized by some people at the meeting for opposing the guest "rudely." Čestmír argued that "He won't be invited anymore, it's open racism in broadcasting!" Martin, one of the heads of news, said: "She disassociated herself from it, (...) I think it's good that she opposed and distanced herself. (...) She is a professional, but she is also a human.” (Field notes)

Opposing a racist "expert" was the host's way of being constructive. James both witnessed the live broadcast and took part in the following meeting and debate. He admired the host's strength and readiness.

Obviously, journalists' political involvement and political opinion on or expertise in a certain situation go hand in hand with their emotional engagement (see "The Journey"). More specifically, the personal indignation against racism or resentment toward people and groups whom the journalists have to meet, talk to, or to whom they are supposed to give voice in the news despite their evident extreme right or even racist ideas/rhetoric (such as Pegida and Bloc against Islam), together with a more or less vague idea of the active political role of the media and reporters themselves, results in the journalists' strong emotional response, as in Sam's case:

Sometimes you can, behind the false kind of objectivity, hide the truth also, eh? If you say, for example, 'the so-called occupied territory in Palestine.' What the hell 'so-called' occupied territories!? These territories are occupied, one country occupies the territory of somebody else! What is wrong with clear linguistics? ... There has been a lot of pressure, for many years, to not call it 'occupied' territory, but to call it 'territory.' ... So linguistics or language is power. It's a part of the narrative, a part of the defiance, who is right and who is wrong.

Cf. Vítek's equally emotional statement on the same territory:

This is totally simple. But totally simple. Both the nations have the right to be here. ... Who is right? Not any one. Both of them. Are they able to reach agreement? Well, not right now. So, is it a problem, when you deal with specific situations, to agree with one or another side? For God's sake, why? There's no reason.

At the same time, the journalists' inevitable involvement in the process of defining a crisis meant that, according to Cyril, in crisis it was more 
important to "distinguish who is more probably right and who is more probably wrong," while not being biased (e.g. Gloria). Which was a task for a superhuman.

The no man's land of the departure lounge that James could see through the little oval window was about to stay behind. While James' train of thought was constantly, as if inevitably, turning to his colleagues' emotional experience, James' airplane was about to head toward the catastrophe. James fastened his seat belt and tightened his grip on the computer on his knees.

\section{An Overview}

The "crisis" in "crisis reporting" does not have only the non-problematic, at-hand meaning of a situation "out there" that reporters and the media are supposed to "cover" and "transmit." On the contrary, for journalists, crisis is defined by its polyphony and multi-level scope.

To James' colleagues, “crisis" meant an inside-the-media, usually organizational, technological, professional, or personnel situation not far from a breakdown; at the same time, it meant an outside-the-media temporary or continuous major negative event with a wide impact on society and the suffering of individuals, including the psychological state of the journalists themselves and even calling into question the very essence of the current phase of modernity with its global risks and insecurities (that are further individualized). It also meant the real and the media-constructed: media did not need crisis less than crisis needed media. All these meanings of "crisis" were interconnected, and resonated or interfered with each other.

As a result, the crisis is a ubiquitous, all-encompassing phenomenon, an environment for life; the journalists live inside the crisis, rather than with it or next to it (cf. Deuze 2011). This also means that journalists simply cannot be mere observers and non-actors. The idea of detachment, impartiality, or professional distance that still forms the core of the objectivistic professional commitment is fallacious (from the epistemological point of view) and utopian (from the point of view of media organizations). Journalists are humans and actors, too (Tandoc and Takahashi 2016; Zelizer and Allan 2011). The journalists' very actorship, the political relevance of their accounts, their endangerment, their witnessing are of crucial importance for their emotional experience-sorrow, moral dilemmas, fear. What is the emotional experience will be explored in more detail in the next chapter. 
The decisive moment, where James could still turn back and choose to withdraw, or to continue, had just passed. He could hear the engine firing up. The plane was about to take off. James was slightly pushed into the softness of his seat by inertia. In a few seconds, he was supposed to lose his footing.

\section{REFERENCES}

Abbott, A. (2005). Linked Ecologies: States and Universities as Environments for Professions. Sociological Theory, 23(3), 245-274.

Agamben, G. (2005). State of Exception. Chicago: The University of Chicago Press. Allan, S., et al. (Eds.). (2000). Environmental Risks and the Media. London: Routledge.

Alsup, J. (2005). Teacher Identity Discourses: Negotiating Personal and Professional Spaces. London: Routledge.

Anderson, B. R. (1991). Imagined Communities: Reflection on the Origin and Spread of Nationalism. London: Verso.

Balčytienè, A., et al. (2015). Oligarchization, de-Westernization and Vulnerability: Media Between Democracy and Authoritarianism in Central and Eastern Europe. A Roundtable Discussion. Journal of Media, Cognition and Communication, 3(1), 119-141.

Beck, U. (1992). Risk Society: Towards a New Modernity. London: SAGE.

Beck, U. (2000). Foreword. In S. Allan et al. (Eds.), Environmental Risks and the Media (pp. xii-xiv). London: Routledge.

Beck, U., \& Beck-Gernsheim, E. (2001). Individualization: Institutionalized Individualism and Its Social and Political Consequences. London: SAGE.

Beck, U., et al. (1994). Reflexive Modernization: Politics, Tradition and Aesthetics in the Modern Social Order. Cambridge: Polity Press.

Ben-Yehuda, H., et al. (2013). When Media and World Politics Meet: Crisis Press Coverage in the Arab-Israel and East-West Conflicts. Media, War and Conflict, 6(1), 71-92.

Bigo, D. (2002). Security and Immigration: Toward a Critique of the Governmentality of Unease. Alternatives, 27, 63-92.

Boltanski, L. (1999). Distant Suffering: Morality, Media and Politics. Cambridge: Cambridge University Press.

Bundy, J., et al. (2017). Crises and Crisis Management: Integration, Interpretation, and Research Development. Journal of Management, 43(6), 1661-1692.

Carlson, M., \& Lewis, S. C. (Eds.). (2015). Boundaries of Journalism: Professionalism, Practices and Participation. London: Routledge.

Carpentier, N., \& Trioen, M. (2010). The Particularity of Objectivity: A Poststructuralist and Psychoanalytical Reading of the Gap Between Objectivity-asa-value and Objectivity-as-a-practice in the 2003 Iraqi War Coverage. Journalism, 11(3), 311-328. 
Coombs, T. W. (2010). Ongoing Crisis Communication. London: SAGE.

Cottle, S. (1998). Ulrich Beck, "A Risk Society" and the Media: A Catastrophic View? European Journal of Communication, 13(1), 5-32.

Cottle, S. (2009). Global Crisis Reporting: Journalism in the Global Age. Maidenhead: Open University Press.

De Peuter, G. (2011). Creative Economy and Labor Precarity: A Contested Convergence. Journal of Communication Inquiry, 35(4), 417-425.

Deuze, M. (2011). Media Life. Media, Culture and Society, 33(1), 137-148.

Du Gay, P. (1996). Consumption and Identity at Work. London: SAGE.

Falkheimer, J., \& Olsson, E. K. (2015). Depoliticizing Terror: The News Framing of the Terrorist Attacks in Norway, 22 July 2011. Media, War and Conflict, $8(1), 70-85$.

Giddens, A. (1990). The Consequences of Modernity. Cambridge: Polity Press.

Giddens, A. (1991). Modernity and Self-Identity: Self and Society in the Late Modern Age. Cambridge: Polity Press.

Harcup, T., \& O’Neill, D. (2001). What Is News? Galtung and Ruge Revisited. Journalism Studies, 2(2), 261-280.

Heaphy, B. (2007). Late Modernity and Social Change. London: Routledge.

Hesmondhalgh, D., \& Baker, S. (2011). Creative Labour: Media Work in Three Cultural Industries. London: Routledge.

Hutchison, E., \& Bleiker, R. (2008). Emotional Reconciliation: Reconstituting Identity and Community After Trauma. European Journal of Social Theory, $11(3), 385-403$.

Kaleta, O. (2017). Migrační režim EU v kontextu trvalého výjimečného stavu. Mezinárodni vztaby, 52(2), 57-74.

Koselleck, R. (2006). Crisis. Journal of the History of Ideas, 67(2), 357-400.

Lasch, C. (1991). The Culture of Narcissism: American Life in an Age of Diminishing Expectations. New York: W. W. Norton \& Company.

McDonald, I. R., \& Lawrence, R. G. (2004). Filling the $24 \times 7$ News Hole: Television News Coverage Following September 11. American Behavioral Scientist, 48(3), 327-340.

Nord, L. W., \& Strömbäck, J. (2003). Making Sense of Different Types of Crises: A Study of the Swedish Media Coverage of the Terror Attacks Against the United States and the U.S. Attacks in Afghanistan. Press/Politics, 8(4), 54-75.

Nord, L. W., \& Strömbäck, J. (2006). Reporting More, Informing Less: A Comparison of the Swedish Media Coverage of September 11 and the Wars in Afghanistan and Iraq. Journalism, 7(1), 85-110.

Olsson, E. K., \& Nord, L. W. (2015). Paving the Way for Crisis Exploitation: The Role of Journalistic Styles and Standards. Journalism, 16(3), 341-358.

Örnebring, H. (2009). Comparative European Journalism: The State of Current Research. Working paper. Oxford: Reuters Institute for the Study of Journalism. Pedelty, M. (1995). War Stories: The Culture of Foreign Correspondents. London: Routledge. 
Peters, C. (2011). Emotion Aside or Emotional Side? Crafting an 'Experience of Involvement' in the News. Journalism, 12(3), 297-316.

Scheper-Hughes, N., \& Lock, M. (1987). The Mindful Body: A Prolegomenon to Future Work in Medical Anthropology. Medical Anthropology Quarterly, 1(1), 6-41.

Schudson, M. (2011). What's Unusual About Covering Politics as Usual. In B. Zelizer \& S. Allan (Eds.), Journalism After September 11 (2nd ed., pp. 44-54). London: Routledge.

Sellnow, T. L., \& Seeger, M. W. (2013). Theorizing Crisis Communication. New Jersey: John Wiley and Sons.

Sreberny, A. (2011). Trauma Talk: Reconfiguring the Inside and Outside. In B. Zelizer \& S. Allan (Eds.), Journalism After September 11 (2nd ed., pp. 292-307). London: Routledge.

Tandoc, E. C., \& Takahashi, B. (2016). Journalists Are Humans, Too: A Phenomenology of Covering the Strongest Storm on Earth. Journalism, $17(1), 1-17$.

The Economist. (2016, September 13). How a Media Mogul Helped Turn Czechs Against Refugees. The Economist. Retrieved from https://www. economist.com/news/europe/21707125-politics-central-and-easterneurope-are-increasingly-driven-businesses-own-media.

Thoresen, S., et al. (2014). Media Participation and Mental Health in Terrorist Attack Survivors. Journal of Traumatic Stress, 27, 639-646.

Touraine, A. (1995). Critique of Modernity. Oxford: Blackwell Publishing.

Tulloch, J., \& Lupton, D. (2001). Risk, the Mass Media and Personal Biography: Revisiting Beck's 'Knowledge, Media and Information Society'. European Journal of Cultural Studies, 4(1), 5-27.

Tumber, H. (2006). The Fear of Living Dangerously: Journalists Who Report on Conflict. International Relations, 20(4), 439-451.

Tumber, H. (2011). Reporting Under Fire: The Physical Safety and Emotional Welfare of Journalists. In B. Zelizer \& S. Allan (Eds.), Journalism After September 11 (2nd ed., pp. 319-334). London: Routledge.

Van Der Meer, TGLA. et al. (2016). Disrupting Gatekeeping Practices: Journalists' Source Selection in Times of Crisis. Journalism. Epub ahead of print 16 May 2016. https://doi.org/10.1177/1464884916648095.

Van Leuven, S., et al. (2013). Foreign Reporting and Sourcing Practices in the Network Sphere: A Quantitative Content Analysis of the Arab Spring in Belgian News Media. New Media and Society, 17(4), 573-591.

Van Loon, J. (2002). Risk and Technological Culture: Towards a Sociology of Virulence. London: Routledge.

Van Zoonen, L. (1998). A Professional, Unreliable, Heroic Marionette (M/F): Structure, Agency and Subjectivity in Contemporary Journalisms. European Journal of Cultural Studies, 1(1), 123-143. 
Vincze, H. O. (2014). 'The Crisis' as a Journalistic Frame in Romanian News Media. European Journal of Communication, 29(5), 567-582.

Wagner, P. (1994). A Sociology of Modernity: Liberty and Discipline. London: Routledge.

Walaski, P. (2011). Risk and Crisis Communications: Methods and Messages. New Jersey: John Wiley and Sons.

Weick, K. E. (1995). Sensemaking in Organizations. London: SAGE.

Zelizer, B., \& Allan, S. (Eds.). (2011). Journalism After September 11 (2nd ed.). London: Routledge.

Open Access This chapter is licensed under the terms of the Creative Commons Attribution 4.0 International License (http://creativecommons.org/licenses/ by $/ 4.0 /$ ), which permits use, sharing, adaptation, distribution and reproduction in any medium or format, as long as you give appropriate credit to the original author(s) and the source, provide a link to the Creative Commons licence and indicate if changes were made.

The images or other third party material in this chapter are included in the chapter's Creative Commons licence, unless indicated otherwise in a credit line to the material. If material is not included in the chapter's Creative Commons licence and your intended use is not permitted by statutory regulation or exceeds the permitted use, you will need to obtain permission directly from the copyright holder.

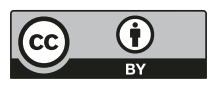

